\title{
SIMULASI SELF DEFENSE SEBAGAI SARANA PEMBELAJARAN MENGHADAPI PEMBAJAKAN PESAWAT KOMERSIAL MENGGUNAKAN METODE FRAME BY FRAME
}

\author{
Nurcahyani Dewi Retnowati, Zikri Mardhatillah \\ Program Studi Teknik Informatika \\ Sekolah Tinggi Teknologi Adisutjipto \\ informatika@stta.ac.id
}

\begin{abstract}
Self defense is a system for defending selfwhich is used to defeat the opponent quickly and without spending a lot of energy. Self defense training is also much needed for pilots and flight attendants, for example to confront the hijacking of commercial flight. Self defense can be trained through the medium of interactive multimedia with $3 D$ animation content. This interactive multimedia was built by using adobe flash professional software, and 3D content using Lightwave $3 D$ software. The result gets from trials to 30 respondents is this learning simulation is used because it is worth more than 50\% of users give good response to simulation as a whole.
\end{abstract}

Keyword : 3D animation, Lightwave, simulation, self defense

\section{Pendahuluan}

Self defense adalah sistem pertahanan diri yang digunakan untuk mematahkan atau melumpuhkan lawan secara cepat tanpa mengeluarkan banyak tenaga atau energi. Dalam mengaplikasikan teknik tehnik self defense ini harus dilakukan dengan penuh perhitungan karena jika salah dalam bertindak maka akan membahayakan keselamatan diri sendiri.

Maraknya aksi kejahatan yang melanda negeri ini seperti: perampokan, pemerkosaan, pembunuhan terjadi silih berganti tidak kenal waktu, tempat dan keadaan. Tidak menutup kemungkinan kejahatan juga terjadi di udara misalnya, pembajakan pesawat. Oleh karena itu sangat di tuntut untuk setiap perusahaan penerbangan supaya memberikan pembekalan teknik self defense khusus untuk pilot dan pramugari. Banyak cara bagi perusahaan penerbangan untuk memberikan pembekalan teknik self defense kepada pilot dan pramugarinya salah satunya melalui simulasi animasi tiga dimensi.

\section{Metode Penelitian}

\subsection{Animasi}

Animasi berasal dari kata 'to animate' yang artinya membuat seolah-olah hidup dan bergerak. Pengertian animasi adalah film yang berasal dari gambar-gambar yang diolah dengan sedemikian rupa hingga menjadi sebuah gambar bergerak dan bercerita (Bambi B.G : 2013).

\subsection{Animasi Frame}

Animasi Frame merupakan animasi yang dibuat dengan mengubah objek pada setiap frame. Objek - objek tersebut nantinya akan nampak nantinya pada lokasi - lokasi yang berbeda pada layar. Animasi frame adalah salah satu dari sekian banyak jenis animasi yang dibagi berdasarkan teknik pembuatan animasi itu sendiri. 


\subsection{Adobe Flash Professional}

Adobe Flash Professional merupakan sebuah software yang didesain khusus oleh Adobe dan program aplikasi standar authoring tool professional yang digunakan untuk membuat animasi dan bitmap yang sangat menarik untuk keperluan pembangunan situs web yang interaktif dan dinamis. Flash didesain dengan kemampuan untuk membuat animasi dua dimensi yang handal dan ringan sehingga flash banyak digunakan untuk membangun dan memberikan efek animasi pada website, CD Interaktif dan lainnya.

\subsection{LightWave 3D}

LightWave3D adalah sebuah program grafik komputer untuk pemodelan tiga dimensi. animasidan rendering. Software LightWave 3D telah sejak lama dikenal karena kemampuan rendering-nya yang bagus dan antar muka pengguna yang tidak biasa. Keunggulan lain yang dimiliki LightWave adalah struktur layout interface yang user friendly, software yang ringan, dan harga original software yang lebih murah dibandingkan software 3D Studio Max.

\subsection{Simulasi}

Simulasi adalah operasi peniruan dari proses kejadian yang terjadi di dunia nyata yang mensimulasikan sesuatu hal, pertamanya membutuhkan model yang dikembangkan, model ini mewakili karakteristik atau kebiasaan tertentu atau system abstrak tau proses (Robert E.Shanon : 1975). Simulasi digunakan dalam banyak hal seperti simulasi teknologi untuk optimisasi, teknik keselamatan, percobaan, pelatihan, pendidikan dan video games.

\subsection{Self Defense}

Self defense adalah tindakan membeladiri, membela harta atau kekayaan dari orang lain yang dapat membahayakan fisik. Dalam melakukan gerakan self defense diperbolehkan menggunakan benda apapun yang ada di sekitar korban, begitu juga sebaliknya dengan penyerang.

\subsection{Skala Likert}

Skala Likert adalah suatu skala psikometrik yang umum digunakan dalam kuesioner, dan merupakan skala yang paling banyak digunakan dalam riset berupa survei. Penggunaan yang penelitian yang sering menggunakan skala ini adalah bila penelitian menggunakan jenis penelitian survey deskriptif (gambaran). Nama skala ini diambil dari nama penciptanya Rensis Likert, yang menerbitkan suatu laporan yang menjelaskan penggunaannya. Sewaktu menanggapi pertanyaan dalam skala Likert, responden menentukan tingkat persetujuannya terhadap suatu pernyataan dengan memilih salah satu dari pilihan yang tersedia.

\section{PerancanganSistem}

\subsection{Perancangan Konten Animasi Tiga Dimensi}

\subsubsection{Live Video recording}

Live video recording ini berfungsi sebagai video panduan untuk gerakan yang akan dianimasikan di software Lightwave layout
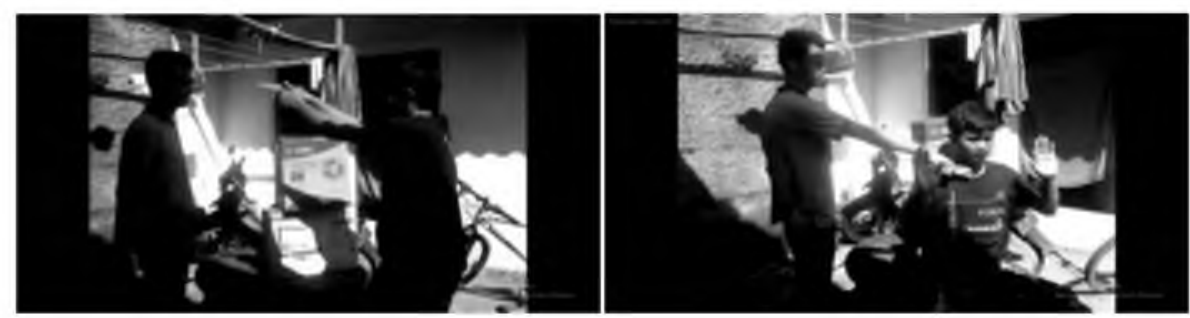

Gambar 1. Live Video Recording 


\subsubsection{Modeling}

Pembuatan model yang akan digunakan dalam konten animasi 3D ini terbagi menjadi dua.
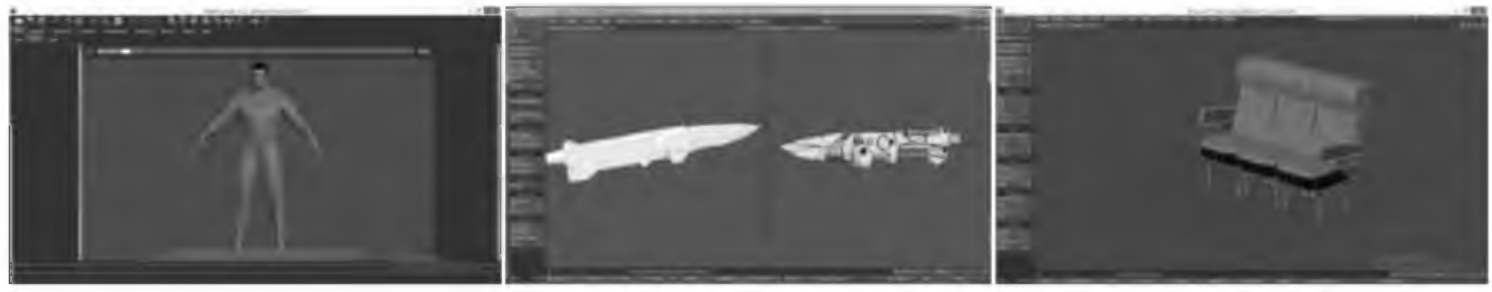

Gambar 2. Modeling

\subsubsection{Texturing}

Proses ini adalah proses pembuatan dan pemberian warna dan material (texture) pada objek yang telah dimodelkan sebelumnya sehingga akan tampak suatu kesan yang nyata. Pemberian texture pada objek tiga dimensi akan mendefinisikan rupa dan jenis bahan dari objek tiga dimensi.

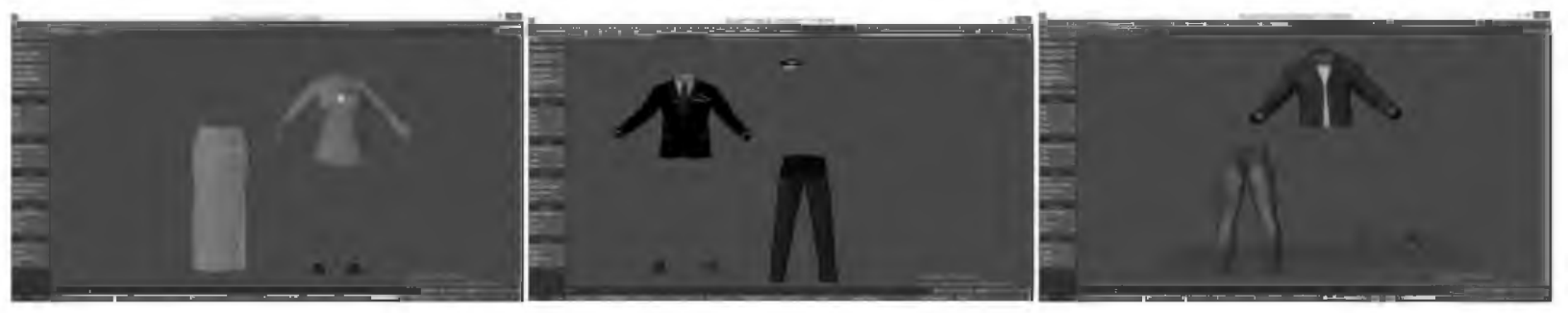

Gambar 3. Pemberian Texture

\subsubsection{Rigging}

Pada proses rigging atau penulangan untuk ketiga karakter ini dilakukan dengan menggunakan preset atau plugin genoma yang sudah ada di softwarelightwave 3D.

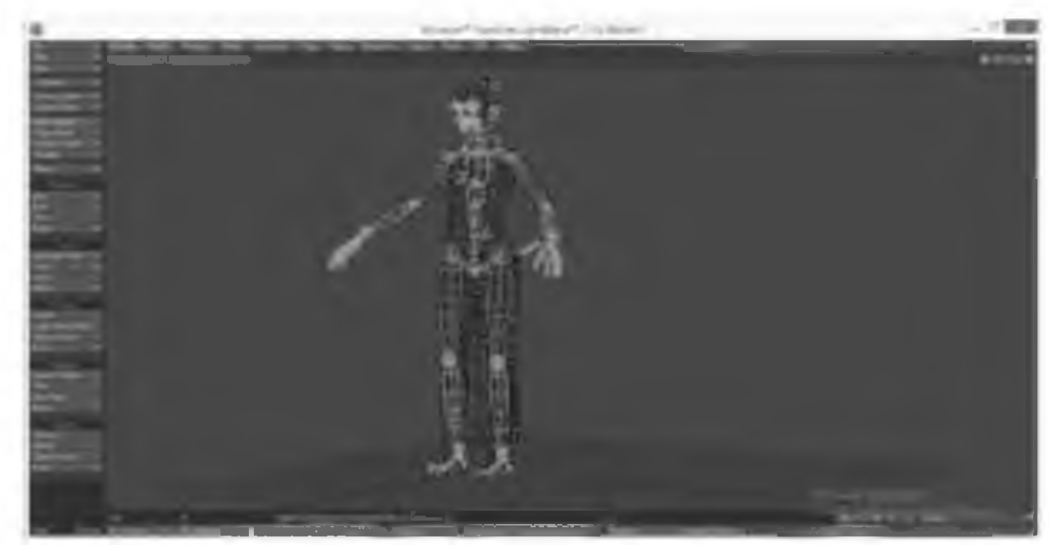

Gambar 4 Rigging atau Penulangan

\subsubsection{Animating}

Karakter mulai digerakkan frame by frame. Pada Gambar 5 karakter digerakkan per-frame sesuai dengan video panduan (live video recording) sehingga pergerakan dari karakter bisa menyerupai gerakan aslinya. 


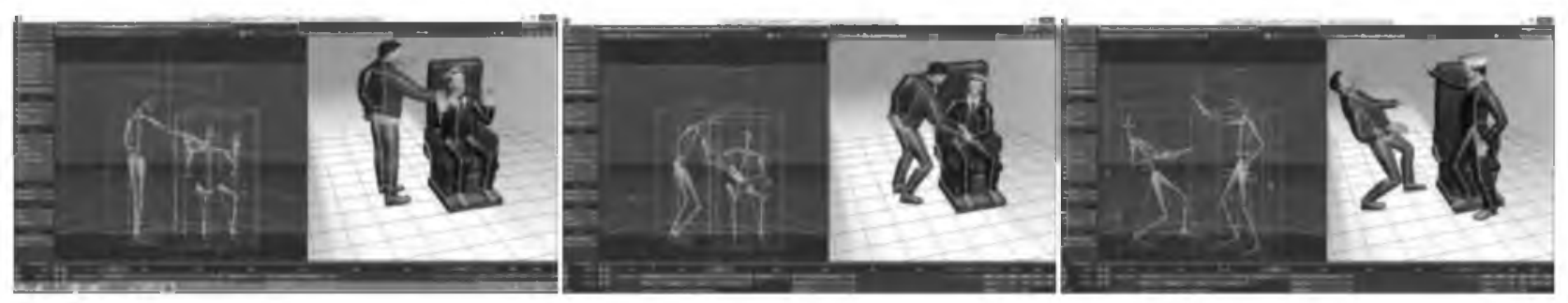

Gambar 5. Proses Animating Frame By Frame

\subsubsection{Lighting}

Penempatan pencahayaan diproses ini diletakkan di tiga point Lighting yang bertujuan supaya mendapatkan pencahayaan maksimal. Supaya pencahayaan tidak terlalu redup ataupun tidak terlalu terang maka dibutuhkan pengaturan intensitas cahaya sesuai yang dibutuhkan. Pengaturan ini dilakukan di properties light seperti yang terdapat pada Gambar 6.
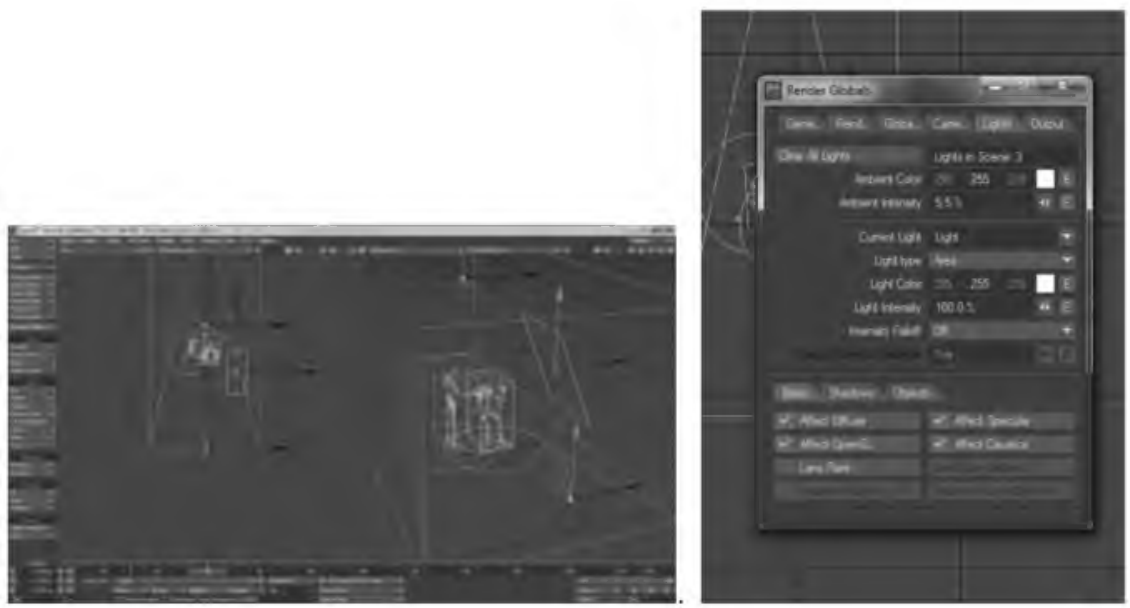

Gambar 6. Lighting Position Dan Pengaturan Intensitas Cahaya

\subsubsection{Rendering}

Dalam melakukan proses rendering ini hal-hal yang perlu diperhatikan diantaranya pengaturan kamera dari segi resolusi, anti aliasing, lensa camera dan lain lain. Setelah pengaturan kamera selesai langkah selanjutnya adalah pengaturan folder output image squence seperti yang diperlihatkan pada Gambar 7. Kemudian masuk ke langkah yang paling penting yaitu tahap akhir dari proses rendering yaitu renderscene dengan cara pilih menu render pada toolbar $>$ renderscene.

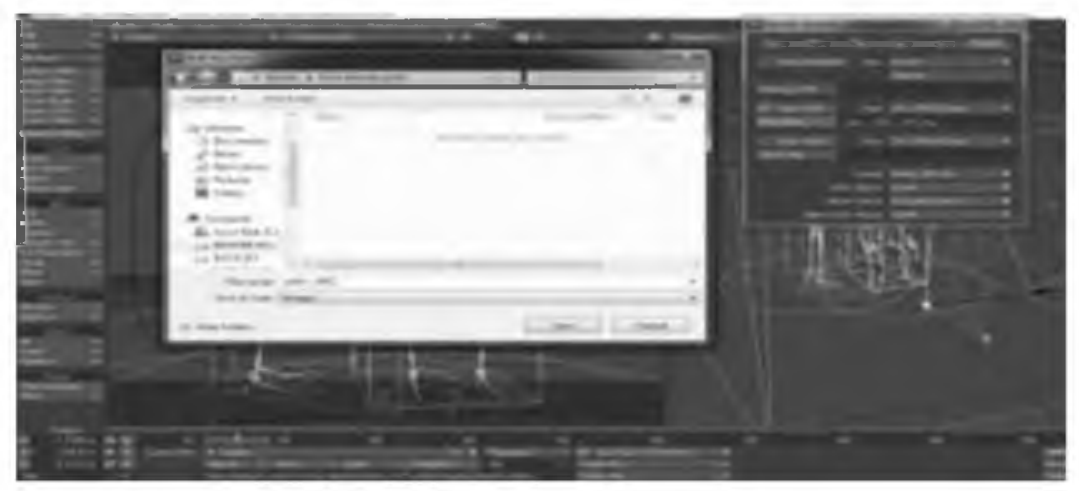

Gambar 7. Output Image Sequence Folder Setting 


\subsubsection{Editing Adobe After Effect}

Di proses ini dilakukan proses penyatuan image sequence menjadi sebuah video animasi yang utuh dengan cara import multiple file pada menu import pada Adobe after effect. Kemudian dilanjutkan dengan pemberian keterangan dari gerakan inti.

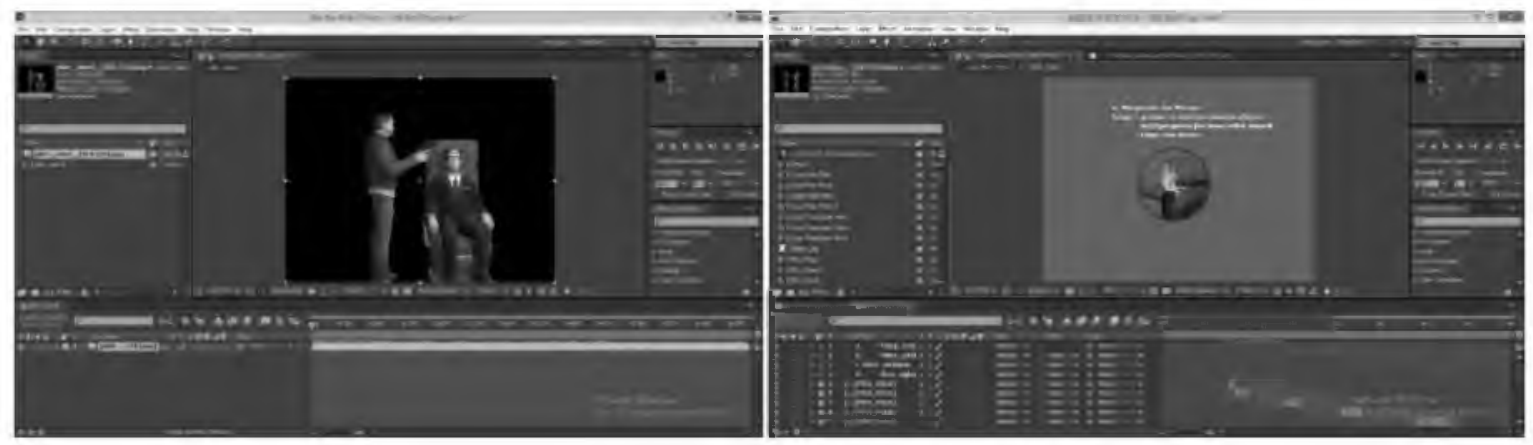

Gambar 8. Penyatuan Image Squence Dan Pemberian Keterangan

\subsubsection{Editing Adobe Premiere}

Di proses editing ini dilakukan penambahan backsound atau suara latar, suara tersebut di-edit sedemikian rupa sehingga sesuai dengan tempo gerakan. Seperti pada Gambar 9.

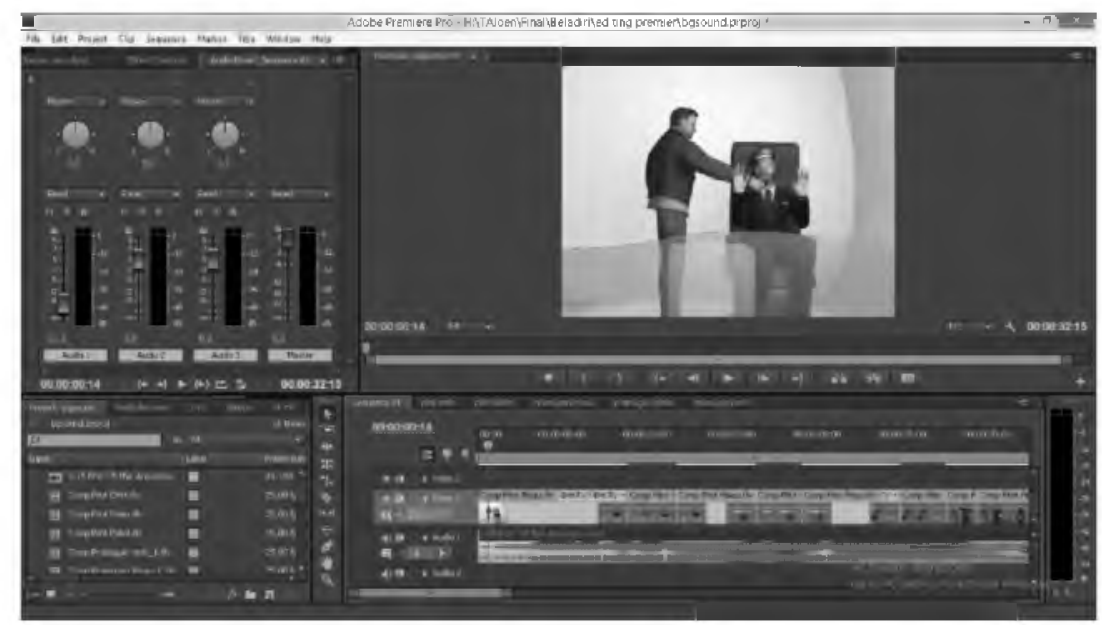

Gambar 9. Proses Pemberian Backsound

\subsection{Perancangan Multimedia Interaktif}

\subsubsection{Form pembuka}

Pada form pembuka ini hanya menampilkan lambang atau logo Sekolah Tinggi Teknologi Adisucipto (STTA). 


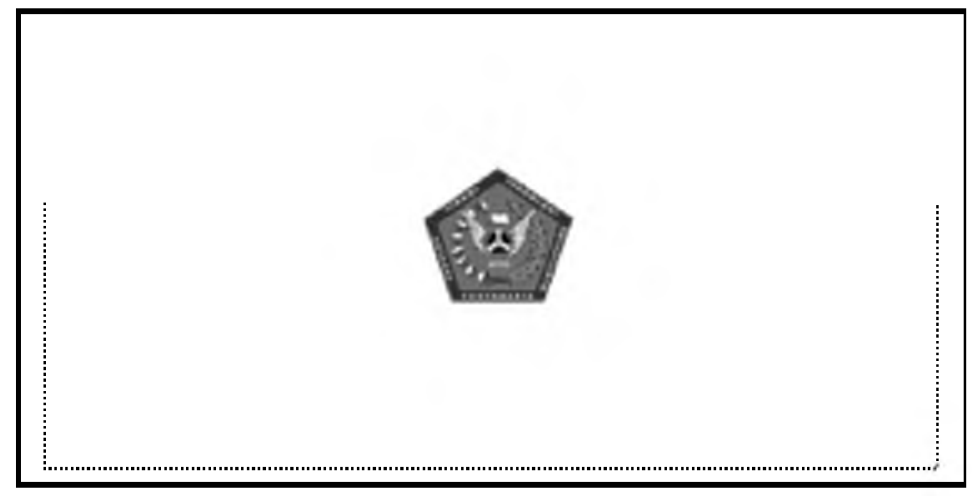

Gambar 10. Form Pembuka

\subsubsection{Form Judul}

Pada tampilan ini terdapat informasi judul dari multimedia interaktif beserta gambar wings, dan ketika gambar wings tersebut di klik maka akan menampilkan halaman utama.

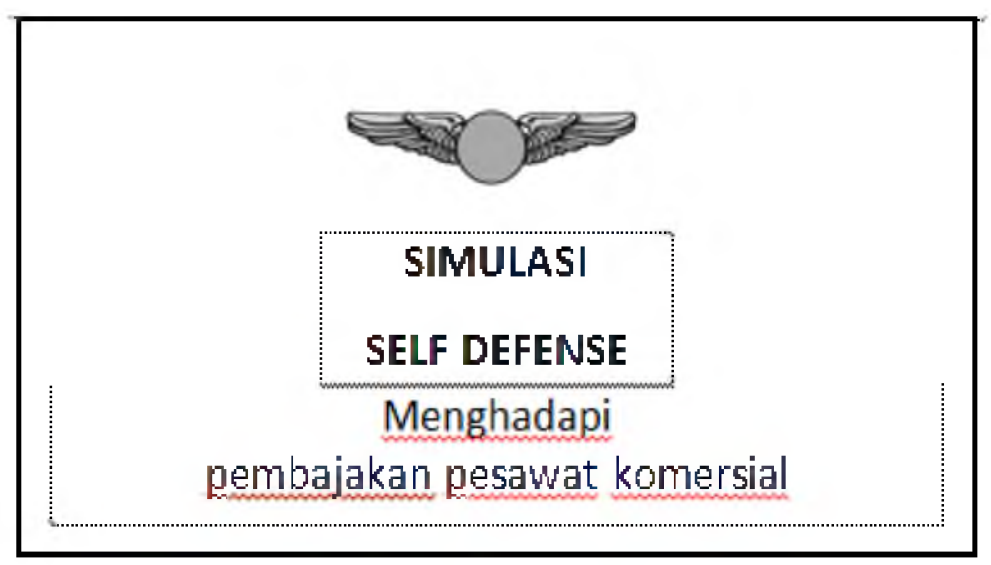

Gambar 11. Form Judul

\subsubsection{Form Utama}

Pada form ini terdapat beberapa menu diantaranya ada menu untuk pilot yang menampilkan beberapa pilihan menu begitu juga dengan pramugari akan menampilkan beberapa menu pilihan. Selain itu di form utama juga terdapat tombol exit dan tombol $i$ atau tombol info.

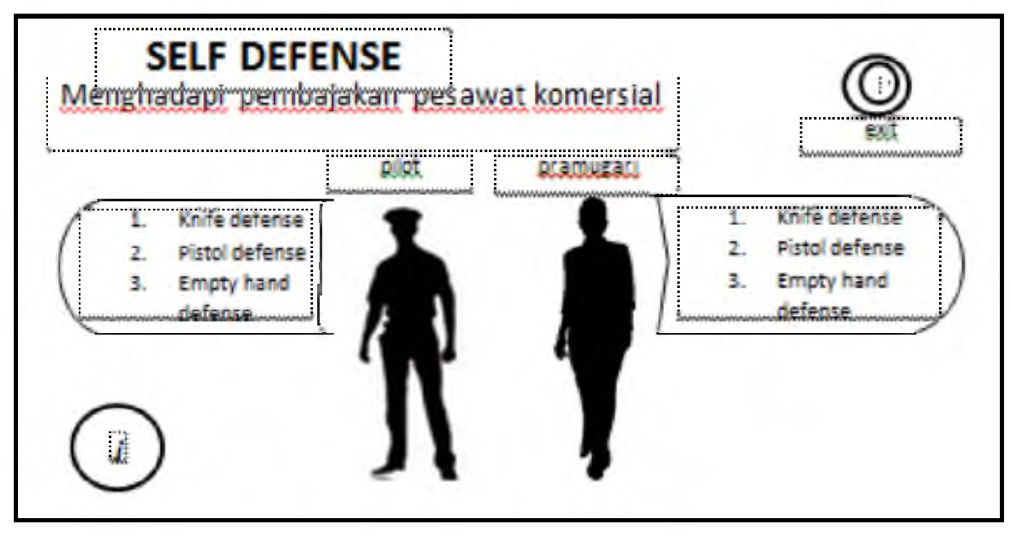

Gambar 12. Form Utama 


\subsubsection{Form Info}

Pada halaman utama terdapat tombol tanda " $i$ " atau tombol info, ketika tombol ini di klik maka akan menampilkan halaman info yang menjelaskan pengertian self defense dan tujuan dari multimedia interaktif ini dibuat.

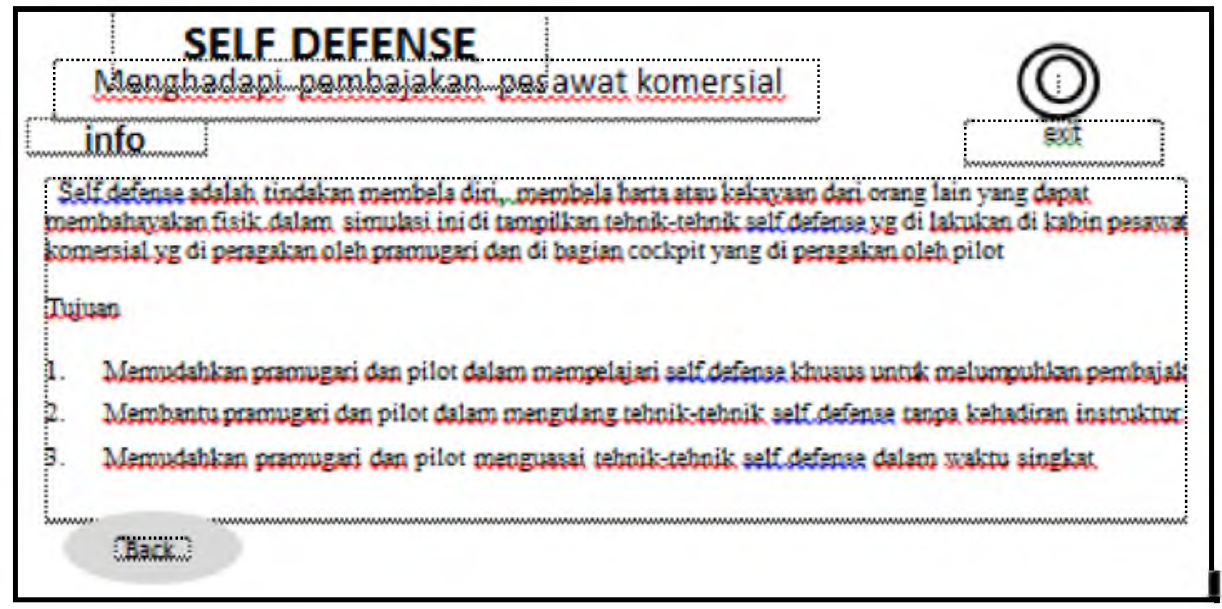

Gambar 13. Form Info

\subsubsection{Form Video}

Pada form utama ini terdapat 2 karakteryaitu karakter pilot dan pramugari, pada masing-masing karakterterdapat tiga menu pilihan yaitu knffe defense, pistol defense dan empty hand defense. Menu-menu ini akan tampil hanya jika cursor diarahkan kearah karakter.Jika salah satu menu di klik maka halaman akan berpindah ke form video, adapun di pemutar video terdapat tombol play, stop, rewind, fast forward dan tombol pengaturan volume. Dan halaman video ini user langsung bisa memilih video mana saja yang ingin ditonton dengan menekan tombol menu yang terdapat di samping tampilan video, dan jika ingin kembali ke menu utama dengan menekan tombol back yang terletak di sebelah kiri atas.

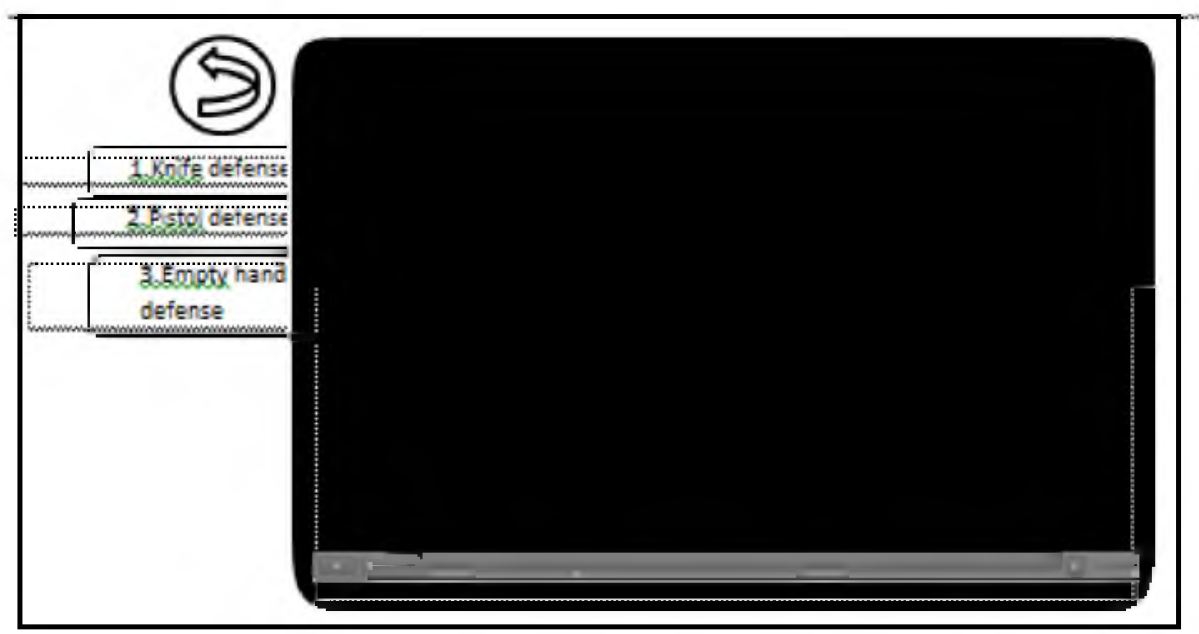

Gambar 14. Form Video 


\subsection{Import Video Animasi Ke dalam Multimedia Interaktif}

Pada proses ini video animasi tiga dimensi yang sudah melalui proses editing sound, di-import kedalam aplikasi multimedia interaktif yang sudah dibuat sebelumnya.

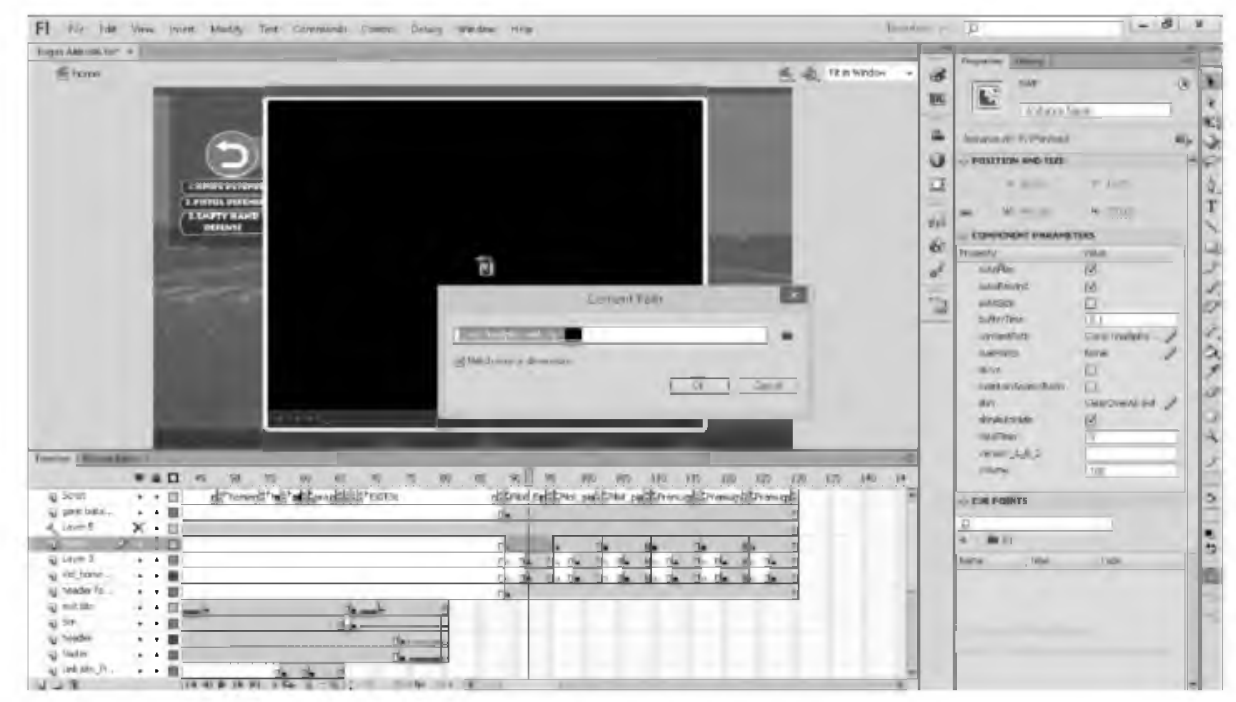

Gambar 15. Import Video Animasi Ke Multimedia Interaktif

\section{Implementasi Dan Pembahasan}

\subsection{Multimedia Interaktif Dan Konten Animasi Tiga Dimensi} dimensi

Berikut ini adalah implementasi dari pembuatan multimedia interaktif dan konten animasi tiga
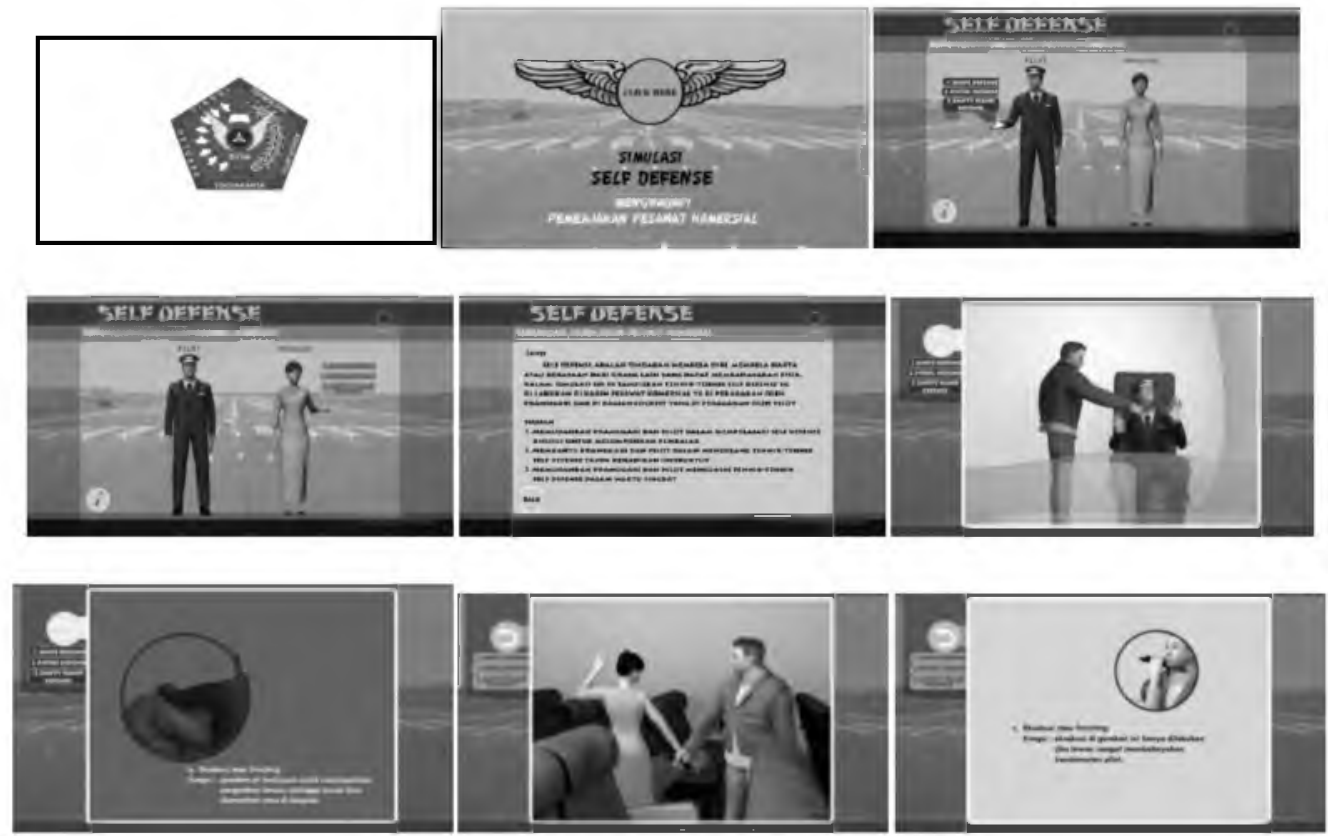

Gambar 16. Implementasi 


\subsection{Uji Fungsi}

Hasil dari animate karakter frame by frame seperti ditunjukkan pada Tabel 1. Frame diambil secara acak sebagai sample.

Tabel 1. Hasil Uji Fungsi

\begin{tabular}{|c|c|c|}
\hline No. & Nomor Frame & Gambar \\
\hline 1. & Frame 120 & \\
\hline 2. & Frame 190 & \\
\hline 3. & Frame 250 & \\
\hline 4. & Frame 260 & \\
\hline 5 . & Frame 280 & \\
\hline
\end{tabular}

\subsection{Uji Coba Pengguna}

Uji coba pengguna dilakukan dengan menggunakan kuisioner dimana melibatkan 30 responden. Perhitungan skor ujicoba pengguna menggunakan skala likert. Adapun interpretasi skornya berdasarkan interval adalah: angka $0 \%-19,99 \%=$ sangat buruk, $20 \%-39,99 \%=$ buruk , $40 \%-$ $59,99 \%=$ cukup, $60 \%-79,99 \%=$ baikdan $80 \%-100 \%=$ sangat baik. Berikut merupakan bentuk pertanyaan yang diajukan kepada responden. Untuk menghitung jumlah keseluruhan jawaban kuesioner maka digunakan rumus yaitu Jumlah data tiap kuesioner / jumlah responden * 100 . 
Tabel 2. Persentase Nilai

\begin{tabular}{|c|c|c|c|c|c|c|}
\hline \multirow{2}{*}{ NO } & \multirow{2}{*}{ EVALUASI } & \multicolumn{5}{|c|}{ NILAI } \\
\hline & & 1 & 2 & 3 & 4 & 5 \\
\hline 1. & $\begin{array}{l}\text { Tingkat user friendly dengan } \\
\text { multimedia interaktif }\end{array}$ & $0 \%$ & $0 \%$ & $13,33 \%$ & $43,33 \%$ & $43,33 \%$ \\
\hline 2. & $\begin{array}{l}\text { Kemudahan dalam mengoperasikan } \\
\text { multimedia interaktif }\end{array}$ & $0 \%$ & $0 \%$ & $0 \%$ & $60 \%$ & $40 \%$ \\
\hline 3. & $\begin{array}{l}\text { Penilaian keseluruhan untuk } \\
\text { tampilan multimedia interaktif }\end{array}$ & $0 \%$ & $0 \%$ & $6,67 \%$ & $60 \%$ & $33,33 \%$ \\
\hline 4. & $\begin{array}{l}\text { Kemudahan user dalam mengikuti } \\
\text { keseluruhan gerakan dari } \\
\text { kontenanimasi 3D }\end{array}$ & $0 \%$ & $6,67 \%$ & $6,67 \%$ & $50 \%$ & $36,67 \%$ \\
\hline 5. & $\begin{array}{l}\text { Kemudahan } \quad \text { user dalam } \\
\text { mempelajari materi-materi } \\
\text { defense yang disajikan }\end{array}$ & $0 \%$ & $0 \%$ & $10 \%$ & $46,67 \%$ & $43,33 \%$ \\
\hline 6. & Materi self defense yang disajikan & $0 \%$ & $3,33 \%$ & $10 \%$ & $60 \%$ & $26,67 \%$ \\
\hline 7. & $\begin{array}{l}\text { Konten animasi 3D dari gerakan } \\
\text { dari karakter pilot }\end{array}$ & $0 \%$ & $0 \%$ & $6,67 \%$ & $53,33 \%$ & $40 \%$ \\
\hline 8. & $\begin{array}{l}\text { Konten animasi } 3 \mathrm{D} \text { dari gerakan } \\
\text { dari karakter pramugari }\end{array}$ & $0 \%$ & $0 \%$ & $6,67 \%$ & $80 \%$ & $13,33 \%$ \\
\hline 9. & Keseluruhan kontenanimasi 3D & $0 \%$ & $0 \%$ & $10 \%$ & $53,33 \%$ & $36,67 \%$ \\
\hline 10. & $\begin{array}{l}\text { Keseluruhan tampilan multimedia } \\
\text { interaktif dan konten animasi 3D }\end{array}$ & $0 \%$ & $0 \%$ & $6,67 \%$ & $46,67 \%$ & $46,67 \%$ \\
\hline
\end{tabular}

\section{Penutup}

\subsection{Kesimpulan}

Berdasarkan hasil pengujian yang telah dilakukan, dapat disimpulkan:

1. Simulasi self defense dengan konten animasi 3D merupakan salah satu sarana pembekalan tehnik-tehnik self defense untuk pilot dan pramugari dalam menghadapi pembajakan pesawat

2. Multimedia interaktif dengan konten animasi 3D ini dapat mempermudah user dalam mempelajari tehnik-tehnik self defense.

3. Dari hasil ujicoba terhadap 30 responden didapatkan hasil bahwa simulasi pembelajaran layak untuk digunakan karena lebih dari $50 \%$ pengguna memberikan respon baik untuk simulasi secara keseluruhan.

\subsection{Saran}

Saran yang dapat digunakan untuk pengembangan selanjutnya antara lain :

1. Untuk pengembangan ke depan, gerakan self defense yang disajikan harus lebih banyak variasinya lagi. 
2. Untuk gerakan merebut pisau yang diperagakan oleh pramugari masih terdapat bugs. Ini dapat diperbaiki di lightwave layout.

3. Multimedia interaktif ini hanya bias dibuka melalui PC, untuk pengembangan selanjutnya aplikasi ini dibuat supaya bias dioperasikan melalui mobile phone.

\section{Daftar Pustaka}

Awaluddin,Teddy. 2008. Membuat 3D Movie Dengan Lightwave 3D v.8.0. Jakarta: Salemba Infotek.

Esfand, Muthia. 2012. Women Self Defense Merdeka Dari Rasa Takut. Jakarta: Visimedia.

Gunawan, Bambi Bambang. 2013. NGANIMASI Bersama Mas Be!. Jakarta : Elex Media Komputindo.

Gorden, Jonny. 2004. Cartoon Character Creation: Volume 1 Modeling \& Texturing. USA: Wordware.

Hari jadi dan Sulisworo, Dwi. 2014. Efektivitas Pembelajaran Simulasi Komputer Pra Eksperimen untuk Meningkatkan Aktivitas Belajar Fisika di SMP Negeri 1 Ponorogo, Prosiding Pertemuan Ilmiah XXVIII HFI Jateng dan DIY, Yogyakarta, 26 April 2014 ISSN : 0853-0823.

Madcoms-Madiun.2012. Kreasi Animasi Kartun dengan Adobe Flash. Yogyakarta: Andi Offset.

Shanon, Robert E. 1975. System Simulation: The Art and science. Eaglewood Cliffs, NJ : PrenticeHall.

Van der byl, Leigh. 2004. Lightwave 3D 8 Texturing, USA: Wordware.

www. satriamultimedia.com/artikel mengenal teori animasi.html, diakses pada 7 September 2015 
Nurcahyani Dewi Retrowati Z Zikri Mardhatillah 